\title{
Comentário:
}

\section{Ser e Temporalidade a parTir de Edith STeIN}

\author{
Martina Korelc ${ }^{1}$
}

Referência do artigo comentado: NUNES, E. P. L. Consciência e temporalidade em Edith Stein: em diálogo com Heidegger. Trans/Form/Açáo: revista de filosofia da Unesp, vol. 44, n. 1, p. 95-116, 2021.

Edith Stein (2006) oferece uma explicação da relação entre a existência, ou o ser da subjetividade, e o tempo, diferente da conhecida interpretação de Heidegger, como também das teses que ela aprendeu de Husserl. A frequentação dos textos da tradição, de Agostinho e Tomás de Aquino, por exemplo, como certamente também o exercício da sua própria reflexão sobre essas questôes, lhe abriram um modo de pensar original. No artigo ora comentado, Nunes (2021) reflete sobre os conceitos de ato e potência, os quais Stein aplica para a explicaçáo do ser da subjetividade, na sua dimensão temporal, como também em outras dimensôes que aqui não serão consideradas. A relação do ser finito, enquanto o ser atual incluindo potencialidades, com o ser plenamente atual que não inclui potencialidade, é interpretada no artigo como um "ser para além do tempo" do Eu. A reflexão sobre a relação entre a existência e o tempo mostra, além disso, que o sentido do ser tem raízes para além da própria subjetividade.

\footnotetext{
${ }_{1}^{1}$ Professora Associada na Universidade Federal de Goiás, Goiânia, GO - Brasil. (DD https://orcid. org/0000-0002-7381-3438 E-mail: martina.ufg@gmail.com

https://doi.org/10.1590/0101-3173.2021.v44n1.08.p121
} 
No presente comentário, pretendo refletir um pouco mais sobre a afirmação da autora do artigo, de que "o eu esteja, pela sua natureza e no seu papel de unificação das vivências, para além do tempo.” Essa afirmação encontra respaldo no texto de Stein (2006, p. 478): "O fato de que possamos acolher em nosso ser algo intemporal [...], demonstra que nosso ser não é absolutamente temporal, que náo se esgota na temporalidade." $\mathrm{O}$ meu objetivo é completar, a partir do pensamento de Edith Stein, essa breve indicação da autora sobre o "para além do tempo".

A autora traz a explicação da relação entre o tempo e a existência, tal como Edith Stein a expóe, no Ser finito e Ser eterno, servindo-se da terminologia e das intuiçóes de H. Conrad-Martius. Segundo essa explicação, não podemos entender a existência da subjetividade a partir do tempo; ao contrário, compreendemos o tempo a partir do conceito da atualidade. Num ponto, no da atualidade, a existência se encontra com o ser, quer dizer, irrompe do nada, recebe o ser. Esse ponto da atualidade, do encontro com o ser, é o presente, o firme ponto cardeal pelo qual o tempo surge. $\mathrm{O}$ ser da subjetividade, o seu existir, é um movimento originário de passagem do nada ao ser, é o devir que contrasta com o nada, por um lado, e com a posse permanente do ser plenamente realizado ou plenamente atual, por outro lado; o tempo seria então o modo como a existência é, ou acontece, o modo como a subjetividade recebe o ser, surgindo ou irrompendo sempre de novo juntamente com os conteúdos vivenciados, sendo posta no ser.

A subjetividade é toda ela constituída por este contato com a plenitude do ser, ela é abertura para o evento do ser que acontece nela. ${ }^{2}$ A atualidade, na consciência, tem a forma do ato da consciência. Mas o ser da subjetividade não se esgota no Eu e no seu ser consciente, este é apenas o "vir à cena" do encontro com a atualidade originária. $\mathrm{O}$ ser que irrompe sempre de novo na subjetividade, com o qual essa é presenteada, precisa do tempo, diz Stein, por não ser pura atualidade, por ser uma passagem da potencialidade à atualidade.

O momento pontual do encontro com o ser é chamado por Stein de instante. O que ocorre nele significa uma "explosão" da temporalidade (STEIN, 2006, p. 477). Ou seja, o instante não é um mero ponto temporal, mas precisamente o contato do temporal com o que não é temporal, a irrupção do não temporal no tempo, que passa pela abertura da subjetividade, pelo seu acolhimento, e exige ao mesmo tempo dedicação e recolhimento, pois

\footnotetext{
${ }^{2} \mathrm{Na}$ fenomenologia, refletiu-se sobre esse evento, chamado aqui de "contato com o ser", também a partir do conceito de doação (MARION, 1997).
} 
o que é oferecido em cada instante pode não ser oferecido novamente, e a consciência dessa unicidade do encontro dá ao tempo sua profundidade. A intensidade ou profundidade do instante ocorre na medida da apropriação do não-temporal, o qual necessita do tempo como sua conservação, porque é um excesso em relaçáo ao momento pontual, um excesso da atualidade plena do ser em relação à atualidade limitada, finita, imbrincada com o potencial.

A atualidade do presente temporal é fugaz; ela, na verdade, não tem em si fundamento para o seu permanecer, sua conservação no tempo. $\mathrm{O}$ fato de que, contudo, há o tempo, sempre de novo um novo presente e uma nova dádiva de ser, experienciada como se conservando temporalmente, aponta para o ser que excede o tempo. O tempo é como a testemunha de que o ser me é dado. O ser da subjetividade é finito, precisamente por isso, por ter necessidade do tempo para chegar a ser o que é, mas também em função de outras determinaçóes, por ser algo colocado no ser, ressalta Stein, por ter uma essência determinada e não ser tudo. Eu só posso acolher o ser de um modo determinado, como este Eu. O que me é dado, o que sou, não o posso acolher inteiramente como atualidade num ponto temporal. Por isso, a atualidade tem para a subjetividade a forma de um vir contínuo, de um escoar para o passado; o que escoa para o passado, como também o que está adiante do meu presente, não volta ao nada. $\mathrm{O}$ eu que sou inclui em si também o eu que fui e que serei, embora não plenamente como atualidade.

Mas o ser finito é compreensível - tem sentido - unicamente pela relação com o ser que está na origem dessa irrupção, que é a atualidade pura sem potencialidade, o ser pleno, atemporal, infinito - o ser eterno. Edith Stein, como também Husserl, Levinas e outros fenomenólogos, diferentemente de Heidegger, afirma que o finito não se compreende sem o infinito, e o ser temporal não se compreende sem o ser atemporal, eterno.

Porque a subjetividade fundamentalmente é em relação com o ser pleno eterno, ela tem sentido e implica em si o náo temporal, ela é uma abertura para além do tempo. A subjetividade recebe o ser juntamente com os conteúdos, isto é, com ela, abre-se o mundo e se mostra algo da sua própria profundidade, como também ela não pode ser sem relaçôes intersubjetivas que, de diferentes modos, determinam esta abertura. Contudo, o que a faz ser, existir, "ter tempo", é essa relação com o ser atemporal. A finitude, e com isso a temporalidade, é uma determinação essencial da existência subjetiva, mas não é a única. 
Também a consideração do ser autêntico revela, segundo Edith Stein, que a existência temporal da subjetividade não esgota o seu sentido. A plenitude do ser que é oferecida à subjetividade em cada instante, através da sua essência individual e única, cuja realização significa para a subjetividade a felicidade à qual aspira, não pode ser acolhida completamente no tempo; o ser autêntico, mesmo pensado ao modo de Heidegger, como a realização das possibilidades mais próprias que se apresentam em cada situação temporal, exige uma intensidade e recolhimento para as quais o tempo é sempre insuficiente, segundo Edith Stein.

O ser de que se trata na existência da subjetividade humana, segundo a fórmula heideggeriana, é essa plena posse de sua essência que está para além da extensão do tempo, na eternidade. Ela desponta no instante, definido como "[...] o recolhimento da extensão temporal na unidade", “[...] o modo de ser em que está superada a diferença entre o instante e a duração" (STEIN, 2006, p. 479), que dá um sentido novo à extensấo do tempo. Na medida em que a subjetividade se abre e se entrega ao ser eterno, o ser temporal se enche de eternidade. $\mathrm{O}$ sentido autêntico da temporalidade é "[...] o modo como o finito obtém a participação no eterno.” (STEIN, 2006, p. 480).

\section{REFERÊNCIAS}

MARION, Jean-Luc. Étant donné. Essai dune phénoménologie de la donation. Paris: PUF, Épiméthée, 1997.

NUNES, E. P. L. Consciência e temporalidade em Edith Stein: em diálogo com Heidegger. Trans/Form/Açáo: revista de filosofia da Unesp, vol. 44, n. 1, p. 95-116, 2021.

STEIN, Edith. Endliches und ewiges Sein. Versuch eines Aufstiegs zum Sinn des Seins. Freiburg: Herder, 2006.

Recebido: 20/10/2020

Aceito: 23/10/2020 